\title{
The behavioural response of the professional buyer on social cues from the vendor and how to measure it
}

\author{
Eveline van Zeeland \\ Department of Design, Production and Management, Faculty of Engineering Technology, University of Twente, \\ Enschede, The Netherlands, and \\ Förg Henseler \\ Department of Design, Faculteit Construerende Technische Wetenschappen, Universiteit Twente, Enschede, The Netherlands
}

\begin{abstract}
Purpose - Vendors' social cues - physical or behavioural hints - have an impact on the professional buyer. However, little is known about that impact. The purpose of this paper is to place knowledge about the impact of social cues that other disciplines acquired in the context of business-tobusiness (B2B) marketing to contribute constructively to the research agenda.

Design/methodology/approach - By integrating findings on the processing of social cues and the behavioural response from the disciplines of neuroscience, biology and psychology (specifically the behavioural inhibition system [BIS]/behavioural activation system [BAS]-theory), this paper aims to provide an interdisciplinary perspective on the automatic evaluation of vendors by professional buyers.

Findings - Social cues are likely to be of substantial value in the (first) encounter between buyer and seller. Positively evaluated social cues create an approach-motivated behavioural intention, whereas negatively evaluated ones create avoidance. This process is probably predominantly mediated by trust and moderated by personality and contextual factors.

Research limitations/implications - This paper stimulates research about the impact of social cues in a B2B context. While such knowledge would add practical value, this paper also explores possibilities for managers to use neuroscientific techniques to assess and train sales agents.

Originality/value - The impact of social cues is hardly covered in the B2B marketing literature, but they have an important impact on B2B decisionmaking. The conceptual framework combines the BIS/BAS theory (approach/avoidance) with the SOR-model (stimulus-organism-response), which is unique to the B2B marketing field.
\end{abstract}

Keywords Buyer-seller relationship, Trust, Social cues, Approach and avoidance, BIS/BAS-theory, Neuroscientific theory

Paper type Conceptual paper

\section{Introduction}

It appears to be difficult to grasp the difference between a successful and an unsuccessful vendor, especially in a businessto-business (B2B) context (Szymanski and Churchill, 1990; Franke and Park, 2006). As there is more interpersonal interaction between sellers and buyers in a B2B context than in a business-to-consumer (B2C) one and there is mostly more at stake (Lynch and Chernatony, 2004), it is relevant to understand the key ingredients of successful vendors, being the "face of the firm" (Javalgi et al., 2014).

With the paradigm shift from marketing instruments targeting transactions to relationship marketing (Grönroos, 1994; LaPlaca and da Silva, 2016), the literature on the success of B2B salespeople has focussed on the selling strategy and behaviour of the vendor. Two literature streams have dominated the personal selling literature: "customer-oriented

The current issue and full text archive of this journal is available on Emerald Insight at: www.emeraldinsight.com/0885-8624.htm

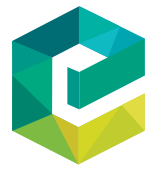

Journal of Business \& Industrial Marketing 33/1 (2018) 72-83

Emerald Publishing Limited [ISSN 0885-8624]

[DOI 10.1108/JBIM-06-2016-0135] selling strategy" (Saxe and Weitz, 1982) and "adaptive selling behaviour" (Weitz et al., 1986). As an effect of the shift from transactional to relational, marketing research focussed on the effects of individual characteristics of the salesperson, such as emotional intelligence (Kadic-Maglajlic et al., 2016), communication skills (Boorom et al., 1998) and intrinsic motivation (Spiro and Weitz, 1990).

However, the positive relationship between a customeroriented selling strategy and/or adaptive selling behaviour on one side and sales performance on the other still has loose ends (Singh and Koshy, 2011). It might be that salespeople believe there is a positive relationship between their customer-oriented

\footnotetext{
(C) Eveline van Zeeland and Jörg Henseler. Published by Emerald Publishing Limited. This article is published under the Creative Commons Attribution (CC BY 4.0) licence. Anyone may reproduce, distribute, translate and create derivative works of this article (for both commercial and non-commercial purposes), subject to full attribution to the original publication and authors. The full terms of this licence may be seen at http://creativecommons.org/licences/by/4.0/legalcode.
}

Received 29 June 2016

Revised 15 October 2016

15 January 2017

4 March 2017

Accepted 5 March 2017 
selling strategy/adaptive selling behaviour and their sales performance, where this is not, or only partly, the case (Franke and Park, 2006). Buyers evaluate more than just the vendor's deliberate selling approach, and this occurs partly automatically and unconsciously. Social cues - verbal or nonverbal hints that can be evaluated positively or negatively - appear to be important guides in this automatic evaluation, although it is hard to make the effect concrete (Leigh and Summers, 2002). Limbu et al. (2016) recently conducted research on the impact of empathy and nonverbal immediacy on sales performance, and highlight that social cues increase nonverbal immediacy. Based on a sample of 422 pharmaceutical sales representatives, they find that adaptive selling behaviour mediates the relationship between empathy and relationship performance. Although adaptive selling behaviour as a mediating variable was not significant with respect to the impact of nonverbal immediacy, the results "point in the right direction" (Limbu et al., 2016, p. 663).

Scholars tend to focus more on developing models to explain behavioural patterns, than on investigating specific stimuli "that function as inputs for psychological mechanisms involved in the decision-making processes giving rise to such patterns" (Haley and Fessler, 2005, p. 247). Nevertheless, it is remarkable how the topic of social cues has been underrepresented in the $\mathrm{B} 2 \mathrm{~B}$ marketing literature. SCOPUS identifies no publication on social cues, or on a related topic like body language, within the context of the (first) encounter between the professional buyer and seller within any of the leading three journals in $\mathrm{B} 2 \mathrm{~B}$ marketing (i.e. IMM, JBIM and JBBM). The broader topic of impression management has deserved research attention, but it is arduous to get information with respect to the unconscious effects on the receiver. If we broaden the scope to the complete field of marketing and sales, the same problem arises. Although we are all aware of the impact of social cues on first impressions, little research attention has been paid to investigate this impact in a selling context (Naylor, 2007; Leigh and Summers, 2002; Bashir and Rule, 2014; Bergeron et al., 2008).

Industrial buying decisions are mostly complex and characterised by group decision-making, which makes it likely that $\mathrm{B} 2 \mathrm{~B}$ buying is by nature more rational than $\mathrm{B} 2 \mathrm{C}$ buying (Lynch and Chernatony, 2004). Over the past years, the role of emotion, subconscious processes and implicit heuristics slowly found its way into the rational world of B2B marketing (Andersen and Kumar, 2006; Leek and Christodoulides, 2012; Hinterhuber and Liozu, 2015; Hinterhuber, 2015). It is likely that industrial buyers are subjected to subconscious processes that influence their decision-making process that are ignored by the traditional-rational point of view (Lynch and Chernatony, 2007; Makkonen et al., 2012). There is every reason to presume that social cues influence the interaction between a professional buyer and seller, just like in any other form of social interaction. Social cues can be processed even when the person is unaware of the stimulus (Gobbini et al., 2013). Other research on the impact of social cues within a professional context that investigated judgements by clinical psychologists about clients' psychological status confirmed that cues affect the judgements made by professionals (Brewer et al., 2011).

Over the past decade, psychologists, neuroscientists and biologists have intensively investigated the impact of social cues. In this paper, the work of those scholars is integrated with the B2B marketing perspective and placed in the context of perceived relationship value. The perceived relationship value influences the behavioural intention of the professional buyer. This paper investigates how this process of impact theoretically works and how the buyers' behavioural response on social cues can best be measured. The paper is structured analogous to the process of influence: social cues are a source of information, this information colours the buyers' perception, which in turn changes their behavioural intentions. Social cues can be physical (e.g. age, gender, clothes and attractiveness) or behavioural (e.g. smiling and gestures; Neu, 2015). Since within the neuroscientific, psychological, biological, economical and marketing literature, the behavioural cues "smiling", "eye gaze" and "gestures", as well as the physical cue "attractiveness", are mostly addressed, this paper concentrates on those cues.

\section{The function of social cues}

Why are professional buyers likely to be sensitive to social cues? The process of buying implies having some kind of relationship with another party. That relationship is in the first place functional by nature, but, especially when personal selling is involved, also has social elements. "To successfully establish and maintain social relationships, individuals need to be sensitive to the thoughts and feelings of others" (Pickett et al., 2004, p. 1095). Interpersonal sensitivity is reflected in the ability to detect and decode social cues. Social cues direct attention, entail valuable information that guides social interaction and are crucial for the first-impression effect.

\section{Social cues direct attention}

The social world is filled with stimuli. As it is impossible to pay attention to every stimulus, we use social cues to direct our attention to the important ones. In a study with 55 nine-montholds, social cues directed the attention of the babies more effectively than non-social ones (Barry et al., 2015). There are good reasons to assume that neurons in specific brain areas are dedicated to processing relevant social cues (Gobbini et al., 2013; Greene and Zaidel, 2011), although some scholars promote the idea of "whole brain" processing of social cues through different mechanisms (Adams and Kveraga, 2015). The amygdala, a brain region that is associated with processing emotions, directs the eyes towards salient stimuli, which are often the eyes of others (Gosselin et al., 2011). The onset of direct eye gaze attracts attention, as the receiver of the gaze is "told" that he or she is being addressed, and that the subsequent action or information will be meaningful (Böckler et al., 2014). This "attentional cueing effect" of eye gaze is obligatory: our attention shifts in the direction of the gaze even if we are told that the direction of gaze has no predictive value (Hood et al., 2003; Friesen and Kingstone, 1998). Therefore, the attentional cueing effect of eye gaze is reflexive and thus automatic: we simply cannot ignore the eye gaze of others.

Besides eye gaze also gestures, the unconsciously produced movements of the hands during speech, direct attention. Gestures can help the receiver of the communication to stay focussed and to pay attention to crucial elements in the message from the perspective of the sender, to memorise the content 
better and to gain a deeper understanding of the content of the communication (Kang et al., 2013).

\section{Social cues as a source of information}

People are focussed on social cues because of a need for information. In other words, we use social cues as hints because social interaction is complex, with much at stake. As the other might do harm (cheating or not honouring commitments), people constantly try to figure out others' intentions. This process is also called mentalising, and social cues appear to activate brain regions associated with mentalising (Straube et al., 2010). As the verbal message of the other does not always reveal somebody's intentions, people rely on social cues which they can recognise rapidly as they are innately prepared to do so (Gobbini et al., 2013; Adams and Kveraga, 2015). In some cases, content might even be largely irrelevant, and social cues predominate (McConnell et al., 2008).

Gestures, for example, are a natural and effective form of communication (Jacobs and Garnham, 2007). Gestures that accompany speech are assumed to give the receiver information about the feelings, emotions and attitudes of the speaker (Goldin-Meadow, 1999). Gestures can even be a "vehicle for the expression of information that is unlikely to be expressed in the accompanying speech" (Cook and Tanenhaus, 2009, p. 102). In other words, gestures entail a communication benefit, and the size of this benefit is defined by the type of gesture (Kang et al., 2013).

\section{Social cues and first impressions}

When does the professional buyer "rely" on social cues the most? Social cues are specifically impactful in the context of first impressions. The relevance of making a "good" first impression within the context of B2B buying has been acknowledged for decades (Young et al., 1994; Swan et al., 1985; Mandják et al., 2016; Clark and Salaman, 1998; Bergeron et al., 2008). Social cues are used as a source of information to assess the potential seller and to make inferences about the intentions of the selling party (mentalising). Dwyer et al. (1987) describe different stages of business relationship development, and it is likely that social cues have the biggest impact in the second stage of "exploration". Social cues will have specific influence in the sub-process of "attraction". This is the phase where potential partners explore the attractiveness of the other, with social cues as additional information sources (Levinger, 1980; Wilson, 1995). The buyer wants information about the likelihood of a profitable partnership as soon as possible:

Natural selection can be expected to have shaped human psychology to be exquisitely sensitive to cues that are (or were, under ancestral conditions) informative with respect to the likely profitability of cooperation in a given situation (Haley and Fessler, 2005, pp. 248-249).

In a commercial context, it was shown that the inferences people make based on their social cues can be surprisingly accurate with respect to the service provider's performance, and of strong influence on the first impression created by the receiver, even before actual interaction between buyer and seller (Naylor, 2007). This leads to the following proposition:
P1. Social cues have the biggest impact during the first seconds of the first interpersonal encounter between seller and buyer.

\section{Social cues and perceived relationship value}

Social cues direct attention and are used as a source of information, which is specifically of impact when making first impressions. In this section, the elements of that impact are explored. We use social cues as an additional source of information to figure out the others' intentions. The information provided by social cues colours the way the buyer perceives the seller, the product or service to be sold and thus the perceived value for the buyer.

With the paradigm shift from a transactional to a relational approach, the definition of value changed from value from a company's perspective to value from a customers' perspective (Tynan et al., 2014). Subsequently, "value-in-use" altered into "value-in-context" in which value creation is perceived in the context of a larger value-configuration space where multiple networks meet (Vargo, 2008). Within the field of industrial marketing, most scholars nowadays concentrate on "relationship value", in which "the nature of the interaction between supplier and customer is critical in the creation of joint value" (Lindgreen et al., 2012, p. 209). The term value always implies some kind of cost-benefit analysis (Ulaga, 2003; Zeithaml, 1988). However, within the context of a relationship these costs and benefits are in part intangible and invisible. This implies that the perception of costs and benefits within the context of a relationship is crucial (Lindgreen et al., 2012). These perceptions are influenced by the evaluation of social cues.

\section{Attitude change}

The way we perceive social cues influences our attitudes towards the other in many ways. The social cue that, with respect to attitude change, has attracted the most attention by marketing and sales scholars is attractiveness (Joseph, 1982; Till and Busler 2000; Ahearne et al., 1999; McColl and Truong, 2013). In general, those studies found positive effects of attractiveness on the attitudes of buyers. This is congruent with the reward-perspective of attractiveness from the neuroscientific literature. An attractive face stimulates a more intense brain response than an unattractive one (Morgan and Kisley, 2014). The brain region that responds strongly to facial attractiveness is the medial orbitofrontal cortex, of which activation is associated with a sense of reward, especially when the beautiful face is garnished with a smile (O'Doherty et al., 2003). Specifically, smiling creates leniency and a milder attitude by the receiver of the smile (LaFrance and Hecht, 1995).

Beauty is considered as an indicator of fitness, and therefore influences the inferences others make about the person. When confronted with an attractive trustee in the game, subjects invest more money (Wilson and Eckel, 2006). But there is also a "beauty penalty" at stake: when beautiful people do not live up to the high expectations, they are punished. So, beauty is not always best (Bower and Landreth, 2001). An explanation for the contradicting findings on the relationship between attractiveness and buyers' attitudes can be found in the 
match-up hypothesis, which states that the image of the spokesperson should match up with the image of the product to be of positive impact (Kamins, 1990). The match-up hypothesis suggests that "what is beautiful is good" should be transformed into "what is expected is good" (Koernig and Page, 2002), indicating that adaptive selling strategies should include not only the adaptive selling behaviour of the salesperson but also sending the right salesperson to the right buyer.

The way we perceive social cues also influences the way we perceive content. A negative message will be perceived as less so when it is accompanied by a smile (Krumhuber and Manstead, 2009). Research on 1,326 participants playing an ultimatum game showed that both good and bad offers proposed by someone who smiled were accepted more than offers from people with a neutral faces and way more than offers from people with angry faces (Mussel et al., 2013). Therefore, the perceived benefits of cooperation are increased by a smile, while the perceived costs are reduced.

When attitudes are alleviated, this might lead to trust and cooperation. Trust has a direct positive effect on buyers' perceived value (Chai et al., 2015). Specifically, attractiveness and smiling are known for their positive effects on trust. In the context of a first encounter, smiling increases trust among strangers and is seen as an intention to cooperate, but only when the smile is genuine (Scharlemann et al., 2001). In a trust game, it was shown that attractive people are trusted more and elicit positive expectations (Wilson and Eckel, 2006). Also, eye gaze can stimulate cooperation. It can create a feeling of being watched and therefore influence peoples' behaviour. For example, when a picture of eyes was placed next to a money box in a university coffee room where consumers had to pay for the coffee out of their own honesty, the contributions by university employees tripled (Bateson et al., 2006).

\section{Variations in the impact of social cues}

According to the elaboration likelihood model (ELM), the impact of social cues on the attitude and judgement of buyers, and therefore on the performance of sellers, might differ based on the buyers' level of involvement (Petty and Cacioppo, 1981). The ELM is a dual-processing model that suggests a central and peripheral route to persuasion. With the central route, individuals take the cognitive effort to evaluate a message. They do so when they are highly involved with the topic. With the peripheral route, individuals evaluate messages with limited cognitive effort, for example processing social cues. As ELM has a cognitive perspective on attitude change, the attitude change created by the peripheral route is suggested to be less durable and less predictive of behaviour. This last point has been heavily debated in literature (Morris et al., 2005; Bitner and Obermiller, 1985; Miniard et al., 1992).

ELM suggests that the impact of social cues is bigger for less involved buyers. Yang et al. (2006) find that people who are less involved with the product develop trust in the seller through the peripheral route in which social cues are more important. In general, buyers are information-searching-orientated or environment-orientated, depending on personality and context factors (Chen and Lee, 2008). Examples of context factors are available resources and time, the level of involvement and motivation of the buyer, and characteristics of the product being sold. Social cues probably have a bigger impact with intangible products, as there are no physical aspects buyers can use as cues to estimate the relationship value (Koernig and Page, 2002; Bitner, 1992). Their impact is probably also bigger for products and services that buyers find difficult to evaluate (Naylor, 2007). The way buyers evaluate cues also depends on their emotional state, which may be attenuated or enhanced by personality traits (Donovan et al., 1994). As an example of a personality factor of influence, Sher and Lee (2009) found that sceptical consumers do not take the central route in attitude change and may be impossible to persuade via argument quality. This leads to the second proposition:

P2. The impact of social cues on attitudes and decisions of the buyer is moderated by personality and context factors.

Despite the moderating effect of personality and context factors, it is unlikely that the impact of social cues is completely absent. Even the most goal-orientated rational buyers will let their estimations of the relationship value be influenced by social cues (Haley and Fessler, 2005). The impact of social cues in the B2B buying context will most likely shrink as time goes by. The business development literature has recognised different business development stages that occur as a function of time (Mandják et al., 2016; Dwyer et al., 1987; Medlin, 2004; Ford, 1980). However, the likelihood of diminishing effects of social cues is difficult to concretise, as business development is not a linear process with clear beginnings and ends (Turnbull et al., 1996; Medlin, 2003; Ford and Hakansson, 2005).

\section{Behavioural response of the buyer: the behavioural inhibition system/behavioural activation system theory}

Table I summarises the effects of the different dominant cues as addressed in the previous sections. However, measuring the actual behavioural response to social cues remains difficult. The limited research on social cues in the marketing and sales domain mostly uses an experimental design in combination with verbal reports. For example, Leigh and Summers (2002) showed manipulated videotapes of a salesperson to 90 professional buyers, who were asked to assess the salesperson's favourability and personality traits on a Likert scale. Such verbal reports do not give an accurate view of a tendency to buy and therefore have limited predictive power. To overcome this, the behavioural inhibition system (BIS)/behavioural activation system (BAS) theory is introduced as a valuable perspective for B2B marketers wanting to measure the impact of social cues on buying potential.

"Emotional faces communicate both the emotional state and the behavioural intentions of an individual. They also activate behavioural tendencies in the perceiver, namely approach or avoidance" (Seidel et al., 2010, p. 500). The value of social cues does not lie in the cues themselves, but in the behavioural response they elicit because of the inferences people make based on these social cues (Neu, 2015). In other words, buyers make inferences on relationship benefits versus costs, which lead to approachor avoidance-motivated behaviour. 
Table I Effects of the behavioural cues smiling, eye gaze and gestures and the physical cue attractiveness

\begin{tabular}{lll}
\hline Social cue & Effects \\
\hline Behavioural cues & Smiling & Creates a milder attitude (LaFrance and Hecht, 1995) \\
& & Negative messages are perceived as less negative (Krumhuber and Manstead, 2009) \\
& Enforces trust and cooperation (Mussel et al., 2013; Scharlemann et al., 2001) \\
& Eye gaze & Direct attention (Böckler et al., 2014; Hood et al., 2003; Friesen and Kingstone, 1998) \\
& Enforces cooperation (Bateson et al., 2006) \\
& Gestures & Direct attention (Kang et al., 2013) \\
& Can express information that is unlikely to be expressed in the accompanying speech (Cook and Tanenhaus, 2009) \\
Physical cue & Creates a positive attitude and a feeling of reward (O'Doherty et al., 2003, Joseph, 1982; McColl and Truong, 2013) & \\
& & Enforces trust and cooperation (Wilson and Eckel, 2006) \\
& Beauty penalty when expectations are not met (Bower and Landreth, 2001; Koernig and Page, 2002)
\end{tabular}

Notes: Increases communication ability, likeability, expertise, and trustworthiness (Ahearne et al., 1999)

Approach and avoidance, the two opposites in human behaviour and motivation, are specifically brought forward by Gray (1982), although the distinction came from the Greeks (Elliot, 2006). The central idea that behaviour is directed by two opposing motivational systems is broadly accepted (Puca et al., 2006). Gray (1982) introduced the BIS/BAS theory in which the BIS and the BAS control human behaviour. The BIS is related to the response to threats, is sensitive for signals of punishment or novelty and is associated with avoidance or withdrawal. The BAS is related to the response to rewarding incentives and thus to a motivation of approach (Smits and Boeck, 2006; Sutton and Davidson, 1997). The BIS/BAS theory, also called the reinforcement sensitivity theory, is one of the most accepted and dominant biology-based theories in psychology (De Pascalis et al., 2013).

Based on physical and behavioural social cues, people make inferences about someone's personality, trustworthiness and goals, of which trustworthiness is the central variable (Neu, 2015). Trust can be seen as the main mediating variable between stimulus and (approach or avoidance) response, especially in a B2B context, and it is not surprising that the topic of trust has dominated the current B2B marketing literature (Young et al., 2015; Scharlemann et al., 2001). Trust is mostly defined as "the perceived credibility and benevolence of a target of trust" (Doney and Cannon, 1997, p. 36) and trust has been found to have a great impact on satisfaction and long-term orientation in business channel relationships (Geyskens et al., 1998). In general, the chain relationship between trust, buyers' perceived value and behavioural intention has been recognised (Chai et al., 2015). Within the neuroscientific, biological and psychological literature, trust has often been linked to approach-motivated behaviour, and the absence of trust with avoidance-motivated behaviour (Todorov, 2008; Bzdok et al., 2011; Chen and Bargh, 1999; Kosfeld et al., 2005). To see trust in the light of the behaviour it provokes (approach vs avoidance) instead of the elements it consists of has a greater commercial value for practitioners, as it shows an explanatory/predictive mindset, compared to a descriptive one (LaPlaca and da Silva, 2016). The conceptual framework (Figure 1) reflects this line of reasoning and can be summarised with the following proposition:

P3. Social cues influence the approach- or avoidancemotivated behaviour of professional buyers, with trust as the key mediating variable.
Here, we see the relationship value of social cues. Positively evaluated social cues create a sense of trust which increases perceived benefits of the relationship and decreases perceived costs, resulting in approach-motivated behaviour. Trust is a form of increased vulnerability. Experimental research showed that in a trust game we place more trust in others that look like ourselves (DeBruine, 2002). The same applies to business partner selection: We tend to select familiar partners (Mandják et al., 2015). Especially in the first stage of relationship development, the uncertainty and accompanied perceived risk play a huge role (Rousseau et al., 1998).

The level of uncertainty is highest for markets where the product is intangible and where its price does not necessarily reflect its end value, such as consultancy services (Glückler and Armbrüster, 2003). This comes down to classical information asymmetry:

Ascertaining the quality of a consultancy's service at the pre-purchase stage is a major problem for clients, since whereas the supplier may know the level of service quality, the buyer often does not (Clark and Salaman, 1998, p. 20).

Price is not a good quality predictor in the consultancy market, which makes social cues a more relevant information source. Characteristics of the product being sold (tangible vs intangible) and the associated level of uncertainty might be the most important contextual factors (Figure 1):

P4. The impact of social cues as a source of information in the partner selection process is bigger for markets where intangible products are sold (service industry) and where the level of uncertainty is highest.

\section{Measuring the impact of social cues on business- to-business decision-making}

The inferences people make based on social cues are reflected in explicit attitudes - of which people are consciously aware and which can be expressed in verbal reports - and specifically in implicit attitudes - of which people are unaware and which are therefore more difficult to observe (McConnell et al., 2008). For example, negative subliminal primes, or masked stimuli can result in negative implicit attitudes but nonnegative explicit attitudes (Rydell et al., 2006). Because of the unconscious nature of implicit attitudes, "irregular" research methods may be required. As people are not consciously aware of the impact 
Figure 1 Conceptual framework of the behavioural response to social cues

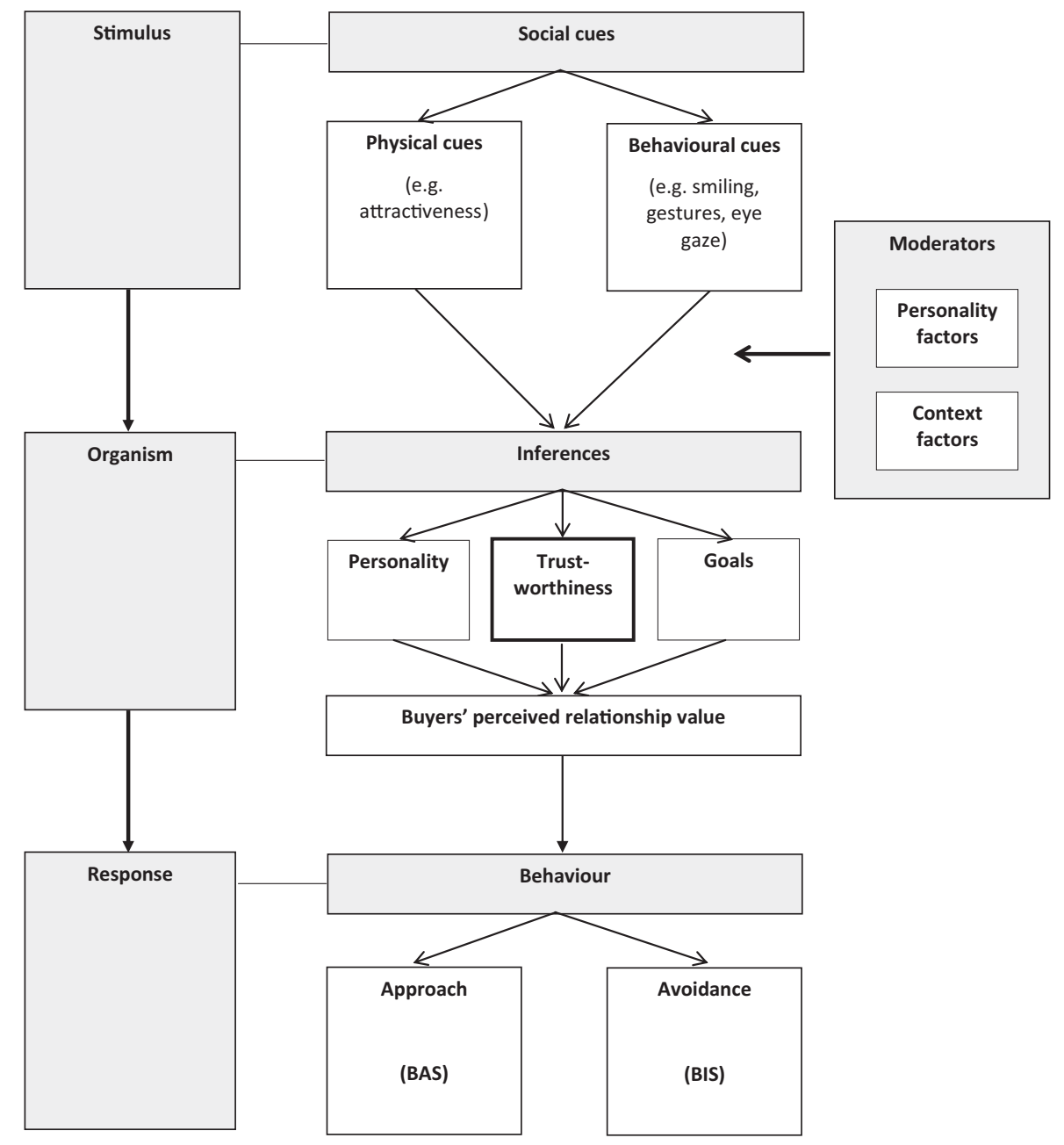

Notes: The SOR framework (stimulus-organism-response) for marketing research (Wang and Minor, 2008) is integrated with the framework of social cues-inferences-behaviour (Neu, 2015) and the BIS/BAS theory related to approach and avoidance (Gray, 1982). Moderating variables are personality factors and context factors which can be explained through the elaboration likelihood model (Petty and Cacioppo, 1981). The dominance of trust as the key mediating variable is in line with the B2B marketing perspective on relationship emergence and development (Geyskens et al., 1998; Mandják et al., 2015; Young et al., 2015). The relationship between trust, buyers' value and behavioural intention is analogous to Chai et al. (2015)

of social cues on their evaluation of the other, verbal self-reports during different phases of the first encounter(s) will not be sufficient. To test the impact of social cues during different moments of the first encounter(s) means we have to "read the minds" of potential buyers at different times. This creates a demand for longitudinal studies and/or sequential experimental methods to test the development of attitudes over time and to bring more dynamics into the buying decision models (Bush et al., 2015; Denant-Boèmont and Petiot, 2003; LaPlaca and da Silva, 2016). Research techniques such as video observation and neuroscientific techniques will make it possible to follow the external expressions and internal neural state of the buyer during the encounter. A nice example forms the research by
Boshoff (2012), who used neuroscientific research techniques to assess the impact of gender and ethnicity during different stages of a service encounter.

\section{The stimulus-organism-response framework}

In the conceptual framework (Figure 1), the stimulusorganism-response (SOR) model is included with a reason. As social cues affect the human mind on both a conscious and unconscious level, measuring the effects of social cues on approach- or avoidance-motivated behaviour is necessary on both levels. As verbal measurement techniques cannot really cover the unconscious level, neuroscientific techniques are suggested. SOR models operate on the presumption that every 
stimulus creates a reaction within the human being (organism) and that this reaction has psychological antecedents and physiological consequences (Wang and Minor, 2008). The psychological antecedents can be both cognitive (for example attention and memory) and affective (e.g. pleasure and arousal).

SOR models demand an experimental research design, which is challenging. Although "experimental control of environmental factors provides a better, more controlled, test of atmospheric factors and the moderating role of subsequent emotional states on shopping behavior" (Yalch and Spangenberg, 2000, p. 139), experimental research designs are practically difficult to use within a B2B context. LaPlaca and da Silva (2016) call on the B2B marketing community to give better explanations for B2B phenomena and to evolve from a descriptive to a predictive science by using other methods and techniques than the standard Likert scales and case studies. The conceptual framework, experimental research design and suggested use of neuroscientific research techniques contribute to realising this. There are positive indications that neuroscientific research techniques in a commercial setting will have a higher predictive power than verbal techniques (Berns and Moore, 2012; Ohme et al., 2010; Venkatraman et al., 2015).

\section{Using neuroscientific techniques to measure buyers' approach/avoidance}

To measure the impact of social cues on approach- versus avoidance-motivated behaviour (P3), we suggest the Davidson model. This model states that approach-motivated behaviour corresponds with greater left over right hemispheric activity in the prefrontal cortex and avoidance-motivated behaviour with greater right over left hemispheric activity, as can be measured with EEG (Davidson, 2003). Greater left over right prefrontal activity corresponds with higher BAS scores and greater right over left prefrontal activity with higher BIS scores (Sutton and Davidson, 1997). In the marketing field, research on advertisements showed that frontal EEG asymmetry is a good diagnostic tool to measure approach- or avoidance-related behaviour (Ohme et al., 2010).

It is important to note that the prefrontal cortex does not serve as a mediator, but rather moderates activity in other parts of the brain, such as the amygdala, that control the primary emotional response to stimuli (Davidson, 2004). Another important aspect is that the direction of motivation should not be mixed with the valence of the motivation (positive or negative; De Pascalis et al., 2013). For example, anger and cognitive dissonance also evoke approach-related behaviour (as measured by a greater left-sided frontal EEG asymmetry), but are related to negative emotions (Harmon-Jones, 2004). The relationship between anger and approach-related behaviour can be explained by aggression or the tendency to attack (Adams et al., 2006). Because this is unlikely in a B2B context, it might be the case that for the buyer-seller dyad the direction and valence of the motivation are more in line.

\section{Managerial and scientific implications}

The themes of interaction and relationships have dominated the B2B marketing literature (Turnbull et al., 1996; Young et al., 2015). First impression effects in a marketing context, like the effects of social cues, are important to understand, because they influence the first stages of B2B relationshipbuilding: selecting and evaluating potential suppliers (Naylor, 2007). The plea of this paper is to focus research attention on social cues and the behavioural responses they provoke.

The adaptive selling framework is of great importance to personal selling theory (Boorom et al., 1998). Within the adaptive selling framework, the seller adapts himself to the buyer, which underlines the idea that there is not one unique selling strategy that in any case leads to the ultimate sales performance (Weitz et al., 1986). One of the possible adaptations a seller consciously or unconsciously can make is by the social cues he or she is detecting and emanating (Franke and Park, 2006; Locander et al., 2014). Practitioners can learn to use social cues effectively. Making salespeople aware of the effects of their social cues should be a key element of effective sales training. The evaluation of the social cues of professionals can also be part of an assessment procedure when hiring new salespeople. In the context of leadership, using neuroscientific techniques during a job application process has been suggested (Waldman et al., 2011).

Scientifically, the perspective of this paper adds value to different literature streams in the field of B2B marketing such as adaptive selling behaviour (ABS), information processing, impression management, and $\mathrm{B} 2 \mathrm{~B}$ relationship emergence and development. This paper has several theoretical and methodological contributions and implications. It introduces BIS/BAS theory into the B2B marketing literature, which contributes to the transformation towards predictive science (LaPlaca and da Silva, 2016; Murphy and Papadopoulos, 2007). This paper supports focusing less on developing new exploratory models and more on the effects of specific stimuli that underlie the behavioural patterns those models try to explain (Hinterhuber and Liozu, 2015). Relevant research questions might be: what is the relative value of the different social cues? Does the same social cue, for example the seller's physical attractiveness, provoke different reactions across industries and people, like the match-up hypothesis describes? Do goal-orientated buyers respond differently to social cues than environment- or relationship-orientated buyers? How durable is the effect of social cues on the buyer's attitude formation? Many more questions can be thought of.

To the knowledge of the authors, SOR models have not been used in B2B marketing research. Although it has been acknowledged that buyers' emotional state influences their response to suppliers, it has been difficult to make those effects concrete (Sheth, 1973; Andersen and Kumar, 2006). There is a need to investigate these effects not only based on explicit attitudes but also on implicit ones (McConnell et al., 2008). This paper's suggestion to use neuroscientific research techniques alongside existing techniques helps to measure the effects of these implicit attitudes. Recently, other scholars also brought neuroscientific techniques to the attention of B2B scholars (Hinterhuber, 2015).

The value of social cues in the $\mathrm{B} 2 \mathrm{~B}$ decision-making process is hypothesised to be highest (a) when the product is intangible and (b) when there is a high degree of uncertainty from the buyer's perspective. In other words, investigating the value of social cues is most relevant for the B2B service industry. According to LaPlaca and da Silva (2016), a lot of work is 
needed in B2B services research and investigating the impact of social cues in the buyer's decision-making process is an additional topic on the research agenda. Within the context of customer loyalty in B2B service markets, it has already been indicated that emotional motivations are stronger than rational motivations, but how this should exactly be interpreted is still vague (Čater and Čater, 2009). Finally, there has been a lot of research on factors that explain the continuation of $\mathrm{B} 2 \mathrm{~B}$ relationships, but only limited attention to the emergence of new relationships (Mandják et al., 2015). As the value of social cues as an information source and as an alleviating factor is probably highest in the exploration phase of potential business relationships, the theme of this paper is of specific relevance to the emergence of B2B relationships literature stream.

\section{Discussion and conclusion}

Buyers probably differ in their vulnerability regarding social cues, just as people differ in the strength of their BIS or BAS and therefore in their response to incentives versus threats (Pickett et al., 2004; McConnell et al., 2008; Sutton and Davidson, 1997; Elliot and Thrash, 2002). Resting patterns of frontal EEG asymmetry have trait-like properties, creating individual different emotional responses (Davidson and Fox, 1989).

The term "irrationality" has been explicitly avoided in this paper. Although the effects of social cues are often described as automatic and emotional, it does not make them irrational. The fact that behavioural differences between buyers cannot fully be explained by functional appeals, does not mean scholars should start a "rationality versus irrationality" debate (Nissan, 2009):

Humans simultaneously use all their brain faculties, developed in different eras of our evolution and seemingly learned to "rationally" adapt their processing mode depending on the situation at hand. Biases, social exchange heuristics and perceptual processing are pushed to the background in deciding to cooperate when ecological information signals profitable opportunities. When the latter is absent, however, they by default take on a more prominent role in decision making and fill in the gap resulting from the absence of strong, guiding incentives (Boone et al., 2008, p. 187).

So it is "rational" to let yourself be guided by social cues whenever other information is not available, as it may prevent the cost of the wrong decision. This paper tries to avoid the "rationality versus irrationality" debate and aims to place the analysis of stimuli that create differences in behavioural patterns on the research agenda.

Perceived social cues in an online setting will probably have an increased impact in the future (Wang et al., 2016). It is suggested that emotional appeals are specifically effective in B2B social media communication (Swani et al., 2014). The impact of online social cues on professional buyers deserves a place on the research agenda as well.

Social cues have value because of the behavioural response they elicit. The behavioural effects in the perceiver of social cues have not been thoroughly investigated, especially not in the context of the buyer-seller dyad in a B2B setting. A genuine smile, an attractive face or good eye contact may all help to guide the potential buyer towards the willing seller. To understand the drivers of approach-motivated behaviour by the professional buyer, further research is needed.

\section{References}

Adams, R.B., Jr., Ambady, N., Macrae, C.N. and Kleck, R.E. (2006), "Emotional expressions forecast approachavoidance behavior", Motivation and Emotion, Vol. 30 No. 2, pp. 179-188.

Adams, R.B., Jr. and Kveraga, K. (2015), "Social vision: functional forecasting and the integration of compound social cues", Review of Philosophy and Psychology, Vol. 6 No. 4, pp. 591-610.

Ahearne, M., Gruen, T.W. and Jarvis, C.B. (1999), "If looks could sell: moderation and mediation of the attractiveness effect on salesperson performance", International fournal of Research in Marketing, Vol. 16 No. 4, pp. 269-284.

Andersen, P. and Kumar, R. (2006), "Emotions, trust and relationship development in business relationships: a conceptual model for buyer-seller dyads", Industrial Marketing Management, Vol. 35 No. 4, pp. 522-535.

Barry, R.A., Estes, K.G. and Rivera, S.M. (2015), "Domain general learning: infants use social and non-social cues when learning object statistics", Frontiers in Psychology, Vol. 6, pp. 1-10.

Bashir, N.Y. and Rule, N.O. (2014), "Shopping under the influence: nonverbal appearance-based communicator cues affect consumer judgments", Psychology \& Marketing, Vol. 31 No. 7, pp. 539-548.

Bateson, M., Nettle, D. and Roberts, G. (2006), "Cues of being watched enhance cooperation in a real-world setting", Biology Letters, Vol. 2 No. 3, pp. 412-414.

Bergeron, J., Fallu, J.M. and Roy, J. (2008), "A comparison of the effects of the first impression and the last impression in a selling context", Recherche et Applications en Marketing (English Edition), Vol. 23 No. 2, pp. 19-36.

Berns, G.S. and Moore, S.E. (2012), "A neural predictor of cultural popularity", fournal of Consumer Psychology, Vol. 22 No. 1, pp. 154-160.

Bitner, M.J. and Obermiller, C. (1985), "The elaboration likelihood model: limitations and extensions in marketing", Advances in Consumer Research, Vol. 12, pp. 420-425.

Bitner, M.J. (1992), "Servicescapes: the impact of physical surroundings on customers and employees", fournal of Marketing, Vol. 56 No. 2, pp. 57-71.

Böckler, A., van der Wel, R.P.R.D. and Welsh, T.N. (2014), "Catching eyes: effects of social and nonsocial cues on attention capture", Psychological Science, Vol. 25 No. 3, pp. 720-727.

Boone, C., Declerck, C.H. and Suetens, S. (2008), "Subtle social cues, explicit incentives and cooperation in social dilemmas", Evolution and Human Behavior, Vol. 29 No. 3, pp. 179-188.

Boorom, M.L., Goolsby, J.R. and Ramsey, R.P. (1998), "Relational communication traits and their effect on adaptiveness and sales performance", Fournal of the Academy of Marketing Science, Vol. 26 No. 1, pp. 16-30.

Boshoff, C. (2012), "A neurophysiological assessment of consumers' emotional responses to service recovery behaviors: the impact of ethnic group and gender similarity", fournal of Service Research, Vol. 15 No. 4, pp. 401-413. 
Bower, A.B. and Landreth, S. (2001), "Is beauty best? Highly versus normally attractive models in advertising", fournal of Advertising, Vol. 30 No. 1, pp. 1-12.

Brewer, N., Barnes, J. and Sauer, J. (2011), "The effects of peripheral message cues on clinicians' judgments about clients' psychological status", British fournal of Clinical Psychology, Vol. 50 No. 1, pp. 67-83.

Bush, V.D., Yang, L. and Hill, K.E. (2015), “The ambivalent consumer: a sequential investigation of response amplification in buyer-seller encounters", Fournal of Marketing Theory and Practice, Vol. 23 No. 4, pp. 402-414.

Bzdok, D., Langner, R., Caspers, S., Kurth, F., Habel, U., Zilles, K., Laird, A. and Eickhoff, S. (2011), "ALE Metaanalysis on facial judgments of trustworthiness and attractiveness", Brain Structure and Function, Vol. 215 Nos 3/4, pp. 209-223.

Čater, B. and Čater, T. (2009), "Emotional and rational motivations for customer loyalty in business-to-business professional services", The Service Industries fournal, Vol. 29 No. 8, pp. 1151-1169.

Chai, J.C.Y., Malhotra, N.K. and Alpert, F. (2015), “A twodimensional model of trust-value-loyalty in service relationships", Fournal of Retailing and Consumer Services, Vol. 26, pp. 23-31.

Chen, M. and Bargh, J. (1999), "Consequences of automatic evaluation: immediate behavioral predispositions to approach or avoid the stimulus", Personality and Social Psychology Bulletin, Vol. 25 No. 2, pp. 215-224.

Chen, S.H. and Lee, K.P. (2008), "The role of personality traits and perceived values in persuasion: an elaboration likelihood model perspective on online shopping", Social Behavior and Personality: An International fournal, Vol. 36 No. 10, pp. 1379-1399.

Clark, T. and Salaman, G. (1998), "Creating the 'right' impression: towards a dramaturgy of management consultancy", Services Industry fournal, Vol. 18 No. 1, pp. 18-38.

Cook, S.W. and Tanenhaus, M.K. (2009), "Embodied communication: speakers' gestures affect listeners' actions", Cognition, Vol. 113 No. 1, pp. 98-104.

Davidson, R. (2004), "What does the prefrontal cortex 'do' in affect: perspectives on frontal EEG asymmetry research", Biological Psychology, Vol. 67 No. 1, pp. 219-233.

Davidson, R.J. (2003), "Affective neuroscience and psychophysiology: toward a synthesis", Psychophysiology, Vol. 40 No. 5, pp. 655-665.

Davidson, R. and Fox, N. (1989), "Frontal brain asymmetry predicts infants' response to maternal separation", fournal of Abnormal Psychology, Vol. 98 No. 2, pp. 127-131.

De Pascalis, V., Cozzuto, G., Caprara, G.V. and Alessandri, G. (2013), "Relations among EEG-alpha asymmetry, BIS/BAS, and dispositional optimism", Biological Psychology, Vol. 94 No. 1, pp. 198-209.

DeBruine, L.M. (2002), "Facial resemblance enhances trust", Proceedings. Biological sciences, Vol. 269 No. 1498, pp. 1307-1312.

Denant-Boèmont, L. and Petiot, R. (2003), "Information value and sequential decision-making in a transport setting: an experimental study", Transportation Research Part B, Vol. 37 No. 4, pp. 365-386.
Doney, P.M. and Cannon, J.P. (1997), “An examination of the nature of trust in buyer-seller relationships", fournal of Marketing, Vol. 61 No. 2, pp. 35-51.

Donovan, R.J., Rossiter, J.R., Marcoolyn, G. and Nesdale, A. (1994), "Store atmosphere and purchasing behavior", Fournal of Retailing, Vol. 70 No. 3, pp. 283-294.

Dwyer, F.R., Schurr, P.H. and Oh, S. (1987), "Developing buyer-seller relationships", fournal of Marketing, Vol. 51 No. 2, pp. 11-27.

Elliot, A.J. (2006), "The hierarchical model of approachavoidance motivation", Motivation and Emotion, Vol. 30 No. 2, pp. 111-116.

Elliot, A.J. and Thrash, T.M. (2002), "Approach-avoidance motivation in personality: approach and avoidance temperaments and goals", Fournal of Personality and Social Psychology, Vol. 82 No. 5, pp. 804-818.

Ford, D. (1980), “The development of buyer-seller relationships in industrial markets", European fournal of Marketing, Vol. 14 Nos 5/6, pp. 339-353.

Ford, D. and Hakansson, H. (2005), "The idea of business interaction", The IMP fournal, Vol. 1 No. 1, pp. 4-20.

Franke, G.R. and Park, J.E. (2006), "Salesperson adaptive selling behavior and customer orientation: a meta-analysis", Fournal of Marketing Research, Vol. 43 No. 4, pp. 693-702.

Friesen, C.K. and Kingstone, A. (1998), "The eyes have it! Reflexive orienting is triggered by nonpredictive gaze", Psychonomic Bulletin E Review, Vol. 5 No. 3, pp. 490-495.

Geyskens, I., Steenkamp, J. and Kumar, N. (1998), "Generalizations about trust in marketing channel relationships using Meta-analysis", International fournal of Research in Marketing, Vol. 15 No. 3, pp. 223-248.

Glückler, J. and Armbrüster, T. (2003), "Bridging uncertainty in management consultancy: the mechanisms of trust and networked reputation", Organization Studies, Vol. 24 No. 2, pp. 269-297.

Gobbini, M.I., Gors, J.D., Halchenko, Y.O., Hughes, H.C. and Cipolli, C. (2013), "Processing of invisible social cues", Consciousness and Cognition, Vol. 22 No. 3, pp. 765-770.

Goldin-Meadow, S. (1999), "The role of gesture in communication and thinking", Trends in Cognitive Sciences, Vol. 3 No. 11, pp. 419-429.

Gosselin, F., Spezio, M.L., Tranel, D. and Adolphs, R. (2011), "Asymmetrical use of eye information from faces following unilateral amygdala damage", Social Cognitive and Affective Neuroscience, Vol. 6 No. 3, pp. 330-337.

Gray, J.A. (1982), The Neuropsychology of Anxiety: An Enquiry into the Functions of the Septo-Hippocampal System, Oxford University Press, Oxford.

Greene, D.J. and Zaidel, E. (2011), "Hemispheric differences in attentional orienting by social cues", Neuropsychologia, Vol. 49 No. 1, pp. 61-68.

Grönroos, C. (1994), "From marketing mix to relationship marketing: towards a paradigm shift in marketing", Management Decision, Vol. 32 No. 2, pp. 4-20.

Haley, K.J. and Fessler, D.M. (2005), "Nobody's watching? Subtle cues affect generosity in an anonymous economic game", Evolution and Human Behavior, Vol. 26 No. 3, pp. 245-256.

Harmon-Jones, E. (2004), "Contributions from research on anger and cognitive dissonance to understanding the 
motivational functions of asymmetrical frontal brain activity”, Biological Psychology, Vol. 67 No. 1, pp. 51-76.

Hinterhuber, A. (2015), "Violations of rational choice principles in pricing decisions", Industrial Marketing Management, Vol. 47, pp. 65-74.

Hinterhuber, A. and Liozu, S. (2015), "Editorial: behavioral and psychological aspects of B2B pricing", Industrial Marketing Management, Vol. 47, pp. 4-5.

Hood, B.M., Macrae, C.N., Cole-Davies, V. and Dias, M. (2003), "Eye remember you: the effects of gaze direction on face recognition in children and adults", Developmental Science, Vol. 6 No. 1, pp. 67-71.

Jacobs, N. and Garnham, A. (2007), "The role of conversational hand gestures in a narrative task", fournal of Memory and Language, Vol. 56 No. 2, pp. 291-303.

Javalgi, R.G., Hall, K.D. and Cavusgil, S.T. (2014), "Corporate entrepreneurship, customer-oriented selling, absorptive capacity, and international sales performance in the international B2B setting: conceptual framework and research propositions", International Business Review, Vol. 23 No. 6, pp. 1193-1202.

Joseph, W.B. (1982), "The credibility of physically attractive communicators: a review", fournal of Advertising, Vol. 11 No. 3, pp. 15-24.

Kadic-Maglajlic, S., Vida, I., Obadia, C. and Plank, R. (2016), "Clarifying the influence of emotional intelligence on salesperson performance", Fournal of Business E Industrial Marketing, Vol. 31 No. 7, pp. 877-888.

Kamins, M.A. (1990), “An investigation into the 'match-up' hypothesis in celebrity advertising: when beauty may be only skin deep", fournal of Advertising, Vol. 19 No. 1, pp. 4-13.

Kang, S., Hallman, G.L., Son, L.K. and Black, J.B. (2013), "The different benefits from different gestures in understanding a concept", fournal of Science Education and Technology, Vol. 22 No. 6, pp. 825-837.

Koernig, S.K. and Page, A.L. (2002), "What if your dentist looked like Tom Cruise? Applying the match-up hypothesis to a service encounter", Psychology and Marketing, Vol. 19 No. 1, pp. 91-110.

Kosfeld, M., Heinrichs, M., Zak, P.J., Fischbacher, U. and Fehr, E. (2005), "Oxytocin increases trust in humans", Nature, Vol. 435 No. 2, pp. 673-676.

Krumhuber, E. and Manstead, A.S.R. (2009), "Are you joking? The moderating role of smiles in the perception of verbal statements", Cognition E Emotion, Vol. 23 No. 8, pp. 1504-1515.

LaFrance, M. and Hecht, M.A. (1995), "Why smiles generate leniency", Personality and Social Psychology Bulletin, Vol. 21 No. 3, pp. 207-214.

LaPlaca, P. and da Silva, R.V. (2016), "B2B: a paradigm shift from economic exchange to behavioral theory: a quest for better explanations and predictions", Psychology \& Marketing, Vol. 33 No. 4, pp. 232-249.

Leek, S. and Christodoulides, G. (2012), "A framework of Brand value in $\mathrm{B} 2 \mathrm{~B}$ markets: the contributing role of functional and emotional components", Industrial Marketing Management, Vol. 41 No. 1, pp. 106-114.

Leigh, T.W. and Summers, J.O. (2002), "An initial evaluation of industrial buyers' impressions of salespersons' nonverbal cues", fournal of Personal Selling $\mathcal{E}$ Sales Management, Vol. 22 No. 1, pp. 41-53.

Levinger, G. (1980), "Toward the analysis of close relationships", fournal of Experimental Social Psychology, Vol. 16 No. 6, pp. 510-544.

Limbu, Y.B., Jayachandran, C., Babin, B.J. and Peterson, R.T. (2016), "Empathy, nonverbal immediacy, and salesperson performance: the mediating role of adaptive selling behavior", fournal of Business E Industrial Marketing, Vol. 31 No. 5, pp. 654-667.

Lindgreen, A., Hingley, M.K., Grant, D.B. and Morgan, R.E. (2012), "Value in business and industrial marketing: past, present, and future", Industrial Marketing Management, Vol. 41 No. 1, pp. 207-214.

Locander, D.A., Mulki, J.P. and Weinberg, F.J. (2014), "How do salespeople make decisions? The role of emotions and deliberation on adaptive selling, and the moderating role of intuition", Psychology \& Marketing, Vol. 31 No. 6, pp. 387-403.

Lynch, J. and Chernatony, L.D. (2004), "The power of emotion: brand communication in business-to-business markets", fournal of Brand Management, Vol. 11 No. 5, pp. 403-419.

Lynch, J. and Chernatony, L.D. (2007), "Winning hearts and minds: business-to-business branding and the role of the salesperson", Fournal of Marketing Management, Vol. 23 Nos 1/2, pp. 123-135.

McColl, R. and Truong, Y. (2013), "The effects of facial attractiveness and gender on customer evaluations during a web-video sales encounter", fournal of Personal Selling $\mathcal{G}$ Sales Management, Vol. 33 No. 1, pp. 117-128.

McConnell, A.R., Rydell, R.J., Strain, L.M. and Mackie, D.M. (2008), "Forming implicit and explicit attitudes toward individuals: social group association cues", fournal of Personality and Social Psychology, Vol. 94 No. 5, pp. 792-807.

Makkonen, H., Olkkonen, R. and Halinen, A. (2012), "Organizational buying as muddling through: a practicetheory approach", fournal of Business Research, Vol. 65 No. 6, pp. 773-780.

Mandják, T., Szalkai, Z., Neumann-Bódi, E., Magyar, M. and Simon, J. (2015), "Emerging relationships: how are they born?”, Industrial Marketing Management, Vol. 49, pp. 32-41.

Mandják, T., Szalkai, Z., Neumann-Bódi, E., Magyar, M. and Simon, J. (2016), “Trigger issues in emerging relationships", Industrial Marketing Management, Vol. 58, pp. 137-147.

Medlin, C.J. (2003), "A dyadic research program: the interaction possibility space model", fournal of Business to Business Marketing, Vol. 10 No. 3, pp. 63-80.

Medlin, C.J. (2004), "Interaction in business relationships: a time perspective", Industrial Marketing Management, Vol. 33 No. 3, pp. 185-193.

Miniard, P.W., Sirdeshmukh, D. and Innis, D.E. (1992), "Peripheral persuasion and Brand choice", fournal of Consumer Research, Vol. 19 No. 2, pp. 226-239.

Morgan, L.K. and Kisley, M.A. (2014), "The effects of facial attractiveness and perceiver's mate value on adaptive allocation of Central processing resources", Evolution and Human Behavior, Vol. 35 No. 2, pp. 96-102.

Morris, J.D., Woo, C. and Singh, A. (2005), "Elaboration likelihood model: a missing intrinsic emotional implication", 
Fournal of Targeting, Measurement and Analysis for Marketing, Vol. 14 No. 1, pp. 79-98.

Murphy, S. and Papadopoulos, N. (2007), "The role of behavioural activation and inhibition in advertising appeals", Proceedings of the ANZMAC Conference, Dunedin, pp. 1584-1592.

Mussel, P., Göritz, A.S. and Hewig, J. (2013), "The value of a smile: facial expression affects ultimatum-game responses", Fudgment and Decision Making, Vol. 8 No. 3, pp. 381-385.

Naylor, R.W. (2007), "Nonverbal cues-based first impressions: impression formation through exposure to static images", Marketing Letters, Vol. 18 No. 3, pp. 165-179.

Neu, W.A. (2015), "Social cues of (un) trustworthy team members", Fournal of Marketing Education, Vol. 37 No. 1, pp. 36-53.

Nissan, E. (2009), "Computational models of the emotions: from models of the emotions of the individual to modelling the emerging irrational behaviour of crowds", $A I$ \& SOCIETY, Vol. 24 No. 4, pp. 403-414.

O’Doherty, J., Winston, J., Critchley, H., Perrett, D., Burt, D. M. and Dolan, R.J. (2003), "Beauty in a smile: the role of medial orbitofrontal cortex in facial attractiveness", Neuropsychologia, Vol. 41 No. 2, pp. 147-155.

Ohme, R., Reykowska, D., Wiener, D. and Choromanska, A. (2010), "Application of frontal EEG asymmetry to advertising research", fournal of Economic Psychology, Vol. 31 No. 5, pp. 785-793.

Petty, R.E. and Cacioppo, J.T. (1981), "The elaboration likelihood model of persuasion", Advances in Experimental Social Psychology, Vol. 19, pp. 123-205.

Pickett, C.L., Gardner, W.L. and Knowles, M. (2004), "Getting a cue: the need to belong and enhanced sensitivity to social cues”, Personality \& Social Psychology Bulletin, Vol. 30 No. 9, pp. 1095-1107.

Puca, R.M., Rinkenauer, G. and Breidenstein, C. (2006), "Individual differences in approach and avoidance movements: how the avoidance motive influences response force", Fournal of Personality, Vol. 74 No. 4, pp. 979-1014.

Rousseau, D.M., Sitkin, S.B., Burt, R.S. and Camerer, C. (1998), "Not so different after all: a cross-discipline view of trust", Academy of Management Review, Vol. 23 No. 3, pp. 393-404.

Rydell, R.J., McConnell, A.R., Mackie, D.M. and Strain, L.M. (2006), "Of two minds: forming and changing valenceinconsistent implicit and explicit attitudes", Psychological Science, Vol. 17 No. 11, pp. 954-958.

Saxe, R. and Weitz, B.A. (1982), "The SOCO scale: a measure of the customer orientation of salespeople", Fournal of Marketing Research, Vol. 19 No. 3, pp. 343-351.

Scharlemann, J.P., Eckel, C.C., Kacelnik, A. and Wilson, R. K. (2001), "The value of a smile: game theory with a human face", fournal of Economic Psychology, Vol. 22 No. 5, pp. 617-640.

Seidel, E.M., Habel, U., Kirschner, M., Gur, R.C. and Derntl, B. (2010), "The impact of facial emotional expressions on behavioral tendencies in women and men", Fournal of Experimental Psychology: Human Perception and Performance, Vol. 36 No. 2, pp. 500-507.

Sher, P.J. and Lee, S.H. (2009), "Consumer skepticism and online reviews: an elaboration likelihood model perspective",
Social Behavior and Personality: An International fournal, Vol. 37 No. 1, pp. 137-143.

Sheth, J.N. (1973), "A model of industrial buyer behavior", fournal of Marketing, Vol. 37 No. 4, pp. 50-56.

Singh, R. and Koshy, A. (2011), "Does salesperson's customer orientation create value in B2B relationships? Empirical evidence from India", Industrial Marketing Management, Vol. 40 No. 1, pp. 78-85.

Smits, D.J.M. and Boeck, P.D. (2006), "From BIS/BAS to the big five", European fournal of Personality, Vol. 20 No. 4, pp. 255-270.

Spiro, R.L. and Weitz, B.A. (1990), "Adaptive selling: conceptualization, measurement, and nomological validity", Fournal of Marketing Research, Vol. 27 No. 1, pp. 61-69.

Straube, B., Green, A., Jansen, A., Chatterjee, A. and Kircher, T. (2010), "Social cues, mentalizing and the neural processing of speech accompanied by gestures", Neuropsychologia, Vol. 48 No. 2, pp. 382-393.

Sutton, S.K. and Davidson, R.J. (1997), "Prefrontal brain asymmetry: a biological substrate of the behavioral approach and inhibition systems", Psychological Science, Vol. 8 No. 3, pp. 204-210.

Swan, J.E., Trawick, I.F. and Silva, D.W. (1985), "How industrial salespeople gain customer trust", Industrial Marketing Management, Vol. 14 No. 3, pp. 203-211.

Swani, K., Brown, B. and Milne, G. (2014), "Should tweets differ for B2B and B2C? An analysis of Fortune 500 companies' Twitter communications", Industrial Marketing Management, Vol. 43 No. 5, pp. 873-881.

Szymanski, D.M. and Churchill, G.A. Jr. (1990), "Client evaluation cues: a comparison of successful and unsuccessful salespeople", fournal of Marketing Research, Vol. 27 No. 2, pp. 163-174.

Till, B.D. and Busler, M. (2000), "The match-up hypothesis: physical attractiveness, expertise, and the role of fit on Brand attitude, purchase intent and Brand beliefs", Fournal of Advertising, Vol. 29 No. 3, pp. 1-13.

Todorov, A. (2008), "Evaluating faces on trustworthiness: an extension of systems for recognition of emotions signaling approach/avoidance behaviors", Annals of the New York Academy of Sciences, Vol. 1124 No. 1, pp. 208-224.

Turnbull, P., Ford, D. and Cunningham, M. (1996), "Interaction, relationships and networks in business markets: an evolving perspective", Fournal of Business \& Industrial Marketing, Vol. 11 Nos 3/4, pp. 44-62.

Tynan, C., McKechnie, S. and Hartley, S. (2014), "Interpreting value in the customer service experience using customer-dominant logic", fournal of Marketing Management, Vol. 30 Nos 9/10, pp. 1058-1081.

Ulaga, W. (2003), "Capturing value creation in business relationships: a customer perspective", Industrial Marketing Management, Vol. 32 No. 8, pp. 677-693.

Vargo, S.L. (2008), "Customer integration and value creation: paradigmatic traps and perspectives", fournal of Service Research, Vol. 11 No. 2, pp. 211-215.

Venkatraman, V., Dimoka, A., Pavlou, P.A., Vo, K., Hampton, W., Bollinger, B., Hershfield, H.E., Ishihara, M. and Winer, R.S. (2015), "Predicting advertising success beyond traditional measures: new insights from neurophysiological methods and market response 
modeling”, fournal of Marketing Research, Vol. 52 No. 4, pp. 436-452.

Waldman, D., Balthazard, P. and Peterson, S. (2011), "Leadership and neuroscience: can we revolutionize the way that inspirational leaders are identified and developed?", Academy of Management Perspectives, Vol. 25 No. 1, pp. 60-74.

Wang, Q., Meng, L., Liu, M., Wang, Q. and Ma, Q. (2016), "How do social-based cues influence consumers' online purchase decisions? An event-related potential study", Electronic Commerce Research, Vol. 16 No. 1, pp. 1-26.

Wang, Y. and Minor, M. (2008), "Validity, reliability, and applicability of psychophysiological techniques in marketing research", Psychology and Marketing, Vol. 25 No. 2, pp. 197-232.

Weitz, B.A., Sujan, H. and Sujan, M. (1986), "Knowledge, motivation, and adaptive behavior: a framework for improving selling effectiveness", Fournal of Marketing, Vol. 50 No. 4, pp. 174-191.

Wilson, D.T. (1995), "An integrated model of buyer-seller relationships", Fournal of the Academy of Marketing Science, Vol. 23 No. 4, pp. 335-345.

Wilson, R.K. and Eckel, C.C. (2006), "Judging a book by its cover: beauty and expectations in the trust game", Political Research Quarterly, Vol. 59 No. 2, pp. 189-202.
Yalch, R.F. and Spangenberg, E.R. (2000), "The effects of music in a retail setting on real and perceived shopping times", Fournal of Business Research, Vol. 49 No. 2, pp. 139-147.

Yang, S.C., Hung, W.C., Sung, K. and Farn, C.K. (2006), "Investigating initial trust toward e-tailers from the elaboration likelihood model perspective", Psychology and Marketing, Vol. 23 No. 5, pp. 429-445.

Young, J.A., Gardner, W.L., III. and Gilbert, F.W. (1994), "Impression management techniques in marketing channels: a theoretical perspective and research agenda", Fournal of Marketing Theory and Practice, Vol. 2 No. 4, pp. 29-38.

Young, L., Wilkinson, I. and Smith, A. (2015), "A scientometric analysis of publications in the journal of business-to-business marketing 1993-2014", fournal of Business-to-Business Marketing, Vol. 22 Nos 1/2, pp. 111-123.

Zeithaml, V.A. (1988), "Consumer perceptions of price, quality, and value: a means-end model and synthesis of evidence”, fournal of Marketing, Vol. 52 No. 3, pp. 2-22.

\section{Corresponding author}

Eveline van Zeeland can be contacted at: e.vanzeelandvanderholst@fontys.nl 